\title{
Perilaku Masyarakat Berdampak Bencana Banjir
}

\author{
Yusup \\ Program Prodi Pendidikan IPS \\ Fakultas Keguruan dan Ilmu Pendidikan \\ Universitas Lambung Mangkurat \\ Banjarmasin \\ e-mail:2010128210007@Mhs.ulm.ac.id
}

\begin{abstract}
Seluruh Negara di Dunia memiliki permasalahan di lingkungan sekirtanya yakni di sebabkan keadaan alam dan manusia itu sendiri. Salah satunya ialah Negara Indonesia yang memiliki wilayah terbesar yang di dalamnya sungguh kaya akan dengan sumber daya alam akan tetapi sunggung memperhatinkan karena sumber daya alamnya sering di maanfaatkan tetapi tidak di perbarui kembali dengan ketentuan dan penyesuaian yang ada itu lah yang disebabkan oleh perilaku manusia. Manusia memiliki perilaku baik dan tidak baik, baik dan tidaknya itu dapat di nilai oleh peristiwa atau kejadian yang terjadi salah satunya ialah bencana banjir yang mana bencana banjir sangat lah mengancam suatu di kehidupan masyarakat maupunn mahluk lainnya yakni memakan korban jiwa, hilangnya tempat tinggal dan sebagainya. Maka dari sekarang lah perlu adanya tindak tegas dan bimbingan terhadap masyarakat untuk bisa menjadikaan lingkungan tetap terjaga walupun setiap kali mengunakan sumber daya alamnya.
\end{abstract}

Keywords: Perilaku,Masyarakat,Banjir.

\section{Pendahuluan}

Negara di Dunia memiliki keindahan masing-masing yang terdapat di dalam Negaranya tersebut. Dari berbagai Negara di Dunia salah satunya ialah Negara Indonesia memiliki keindahan yakni salah satunya ialah memiliki tempat tinggal makhluk hidup seperti manusia, hewan dan tumbuhan. Negara Indonesia memiliki kekayaan alam yang bergitu melimpah akan tetapi masih kekurangnya sumber daya manusia sendiri dalam merawat dan menjaganya. Dalam kehidupan masyarakat tidak lepas dari lingkungan sekirtarnya. Dalam berjalannya waktu pastinya adanya perkembangan yang mana akan menjadi suatu memudahkan masyarakat dalam menjalani kehidupannya.

Hal itu lah menjadikan Perilaku masyakaratnya menjadi suatu tergantungan terhadap sumber daya alamnya karena sangat melimpah menjadikan perilaku tidak baik, sebab adanya perilaku masyarakat hanya mementingkan keperluan yang diinginkan tetapi tidak bisa memperbaiki lagi terhadap keadaan di lingkungan tersebut yang menjadikan sebuah bencana. Salah satu contohnya ialah Bencana Banjir yang disebabkan oleh perilaku masyarakat dalam memenuhi kebutuhan secara berlebihan dalam sumber daya alam yakni pepohonan yang sering di tebang dan pengarukan batu bara tetapi tidak di perbaiki dengan semestinya. 
Perilaku ialah berhubungan dengan perbuatan maupun suatu tindakan orang terhadap suatu yang dilakukan bagaimana meresponnya untuk menjadi suatu kebiasaan sebab adanya suatu nilai yang berpercaya. Secara rasional Perilaku ialah adana respon sesorang dala merangsang dari luar subjek tersbut. Bagaian dari respon ada 2 macam yang berbentuk aktif dan pasif ( Virgatama, D. (2021). Jadi Perilaku merupakan adanya suatu respon terhadap tindakan dari setiap kegiatan manusia yang dapat diamati maupun tidak dengan adanya suatu intraksi/ saling berhubungan satu dengan yang lain yang ada di lingkungan sekitar.

Lingkungan ialah semua faktor dari luar yang saling memperngaruhi suatu organisme hidup (biotic) ialah mahkluk hidup dan tidak hidup (abiotic) yakbi bahan kimia dan energi dan sebagainya. ( Haryanto, M. P. 2018 ). Lingkungan sering menjadi satu permasalhaan dari dunia maka dari itu perlunya suatu pelastarian. Salah satu Negara di dunia ialah Negara Indonesia. Dalam perlestarian alam di Indonesia secara hukum terhadap 2 aturan induk ialah UndangUndang Nomor 05 Tahun 1990 tentang Konservasi Sumber daya Hayati serta Ekosistemnya ialah dalam melestarikan keanekargaman hayati hutan entah di kawasan hutan negara maupun di luar agar dapat melindungi fungsi -fungsi penunjang kehidupan yang di sediakan kawasan hutan. Sedangkan Undang- Undaang Nomor 41 Tahun 1999 mengenai Kehutanan yang menjadikan 2 katagori besar yakni pertama kawasan hutan di lindungi ialah hutan lindung, hutan ini memiliki fungsi pokok untuk perlindungan sistem penyangga dalam kehidupan untur tata air, mencegah banjir,mengendalikan erosi,mencegah instruksi air laut, dan memelihara kesuburan tanah. Kedua Hutan Konservasi, Hutan inii kawasan hutan Negara dengan memiliki ciri khas dengan fungsi pokok pengawetan keanekaragama tumbuhan dan satwa serta ekosistemnya.

Berbagai masalah banyak terjadi dalam suatu kehidupan di lingkungan yakni Kerusakan lahan sebab adanya pengundulan hutan, alih fungsi lahan serta penebangan secar liar untuk pembangunan tantanan industri seperti perkebunan, penambnagan minyak dan perumahaman. Abrasi pinggiran sungai suatu sebabnya ialah jalan para pelayaran kapal-kapal besar. Pendangkalan sungai oleh adanya tinggi dari Abrasi,erosisert sedimentasi. Gangguan pola aliran air permukaan yang disebabkan adanya pengambilan alih lahan,demarga. Penurunan kualitas air akibat dari limbah industri dan limbah domestik.

Masyarakat berdasakan Kamus Besar Bahasa Indonesia (KBBI) ialah sejumah manusia dalam arti luar dan terkait oleh suatu kebudayaaan yang mereka angggap sama. Menurut Paul B Horton dan C Hunt, Masyaraka ialah suatu kumpulan manusia yang sangan relatif mandiri, Hidup bersama-sama dalam waktu yang cukup lama serta bertempat tinggal pada suat wilayah 
tertantu yang memiliki kebudayaan sama serya melakukan sebagian besar kegiatan pada kumpulan manusia tersbut.( Akhmaddhian, S., \& Fathanudien, A. 2015). Jadi Masyarakat ialah kumpulan dari sesorang dalam membentuk sesuatu dan adanya suatu saling berinntraksi satu dengan yang lain dalam tujuan kebersamaan untuk menjalani suatu kehidupan di lingkungan sekitar dan juga mengatasi permasalahan atau isu-isu yang terjadi di tengah mereka.

Pada UU Nomor 24 Tahun 2007 mengenai Penangguangann Bencana. Berbagai Pengertian Bencana sebagai berikut; (Akbar, R., Abedi, N., Handayani, R., \& Eka, U. M. (2017)

1. Bencana ialah kejadian atau urutan suatu kerjadian yang mengancam dan menganggu bagi kehidupan suatu masyarakat. Sebabnya ialah faktor alam maupun faktor non alam serta faktor manusia sehingga berakibat timbul korban jiwa manusia, kerusakan lingkungan, kerugian harta benda serta berdampak pada psikologi.

2. Bencana alam ialah suatu bencana yang mana berakiaat pada kejadian yang disebsbkan oleh gempa bumi, tsunami, Gunung meletus, banjir, kekeringan, angin topan dan tanah longsor.

3. Bencana Non alam ialah bencana dari kejadian suatu peristiwa akibat oleh gagalnya teknologi, gagal modernisasi, epidemi, serta wabah penyakit.

4. Bencana Sosial ialah bencana dari suatu peristiwa yang disebabkan oleh manusia yang meliputi konflik sosial antar kelompok atau antar komunitas masyarakat serta teror.

Bencana alam diantaranya ada 3 jenis yang berdasarkan sebab yakni;

1. Bencana Alam Geologis ialah bencana alam yang di sebebkan oleh adanya pergerakan dalam bumi. Contohnya ialah gempa bumi,tsunami, longsor, gunung berapi dan sebagainya.

2. Bencana Alam Klimatologis ialah suatu bencana dari kejadian disebabkan adanya perubahan iklim, suhu serta cuaca. Contohnya ialah banjir, angin putting beliuang, kekeringan, dan sebagainya.

3. Benca alam ekstra-terestrial ialah bencana dari kerjadian yang disebabkan oleh gaya mamupun energi dari luar bumi yakni hantaman dari benda luar angkasa.

Definisi Banjir ialah suatu peristiwa disuatu tempat adanya genangan air yang melebihi kapasitas dari pembuangan aiir di wilayah tersebut yang menimbulkan suatu kerugian fisik, 
sosial serta ekonomi. Banjir juga acamanan pada setiap musim yang terjadi ketia meluapnya air dari saluran yanng mengenai wilayah tersebut yang sangat merugikan kehidupan makhluk hidup. Banjir ialah suatu kejadian peristiwa dimana dataran kering menjadi terkena tergenang air hingga tempat tersebut memiliki kapalitas air yaanng cukup tidak baik di suatu tempat tersebut yang di sebabkan oleh adanya curah hujan yang sangat tinggi dan topografi wilyahnya rendah sehingga tanahhnya tidak mampu menyerap air sedang berigitu banyaknya dalam waktu yang singkat dan menjadi lama untuk bisa terserap. ( KRISTY, R. 2020 )

\section{Metode}

Metode pada atikel ialah pendekatan deskriftif kualitatif yang mana yang digunakan dalam pengumpulan data mengunakan studi literasi berumpa pengumpulan sumber bacaan seperti artike, jurnal dan buku yang terkait mengenai perilaku masyarakat yang memilik dampak menjadi bencana banjir pada kehidupan di lingkungannya dan menumbuhkan kesadaran terhadap lingkungan yang diinginkan semua orang yang menjadi suatu artikel ini.

\section{Pembahasan}

Pada umumnya suatu masyarakat memiliki kebudayaan masing-masing. Kebudayaan ialah suatu pengetahuan yang mencakup ide serta gagasan dalam pemikiran setiap manusia yang menjadikan dalam kehidupan kebudayaan yang bersifat abstrak. Perwujudan Kebudayaan yakni perilaku dan benda yang bersifat nyata seperti pola perilaku, bahasa, peralayan hidup, organisasi sosial, relegi, seni dan lain lainnya yang keselurhannya untuk keperluan dari kehidupan manusiia dalam masyarakat. ( Subiyakto, B., Mutiani, M., \& Hidayat Putra, M. A. (2019).

\section{Faktor Perilaku Manusia}

Manusia memiliki perilaku yang sangat baik dan tidak dalam mengingkan sesuatu yang diinginkan dalam memenuhi keperluan di kehidupan. Faktor-faktor yang mendorong manusia untuk hidup. Menurut Akhmaddhian, S., \& Fathanudien, A. (2015). Sebagai berikut :

1. Hasrat Sosial ialah keinginan setiap individu untuk menintraksikan diri terhadap sesorang atau kelompok.

2. Hasrat Mempertahankan diri ialah keinginan untuk menjaga diri dalam berbagai dari pengaruh dari luar yang bisa menghampiri dirinya, sehingga seseorang menjadi pendoronh manusia untuk hidup dnegan masyrakat perlu bergabung dengan seseorang lain 
3. Hasrat Berjuang ialah adanya suatu persaingan, keinginan dalam berpendapat orang lain selalu di bantahnya menjadikan satu sama lain menjadi persatujuan untuk tujuan bersama.

4. Hasrat Harga Diri ialah adanya sebuah rasa yang di miliki seseorang untu ingin di akui keberadaannya daan nantinya akan di bandingkan dengan orang lain yang tujuannya ingin di kenal dan di beri sebuah penghargaan.

5. Hasrat Meniru ialah segala susuatu yang menyatakan secara sembuyisembunnya maupun terbuka sebagaimana dari salah satu tindakan.

6. Hasrat Bergaul ialah berkumpul dengan sekelompok orang tertentu dalam suatu masyarakat.

7. Hasrat Ingin Kebebasan ialah keinginan atas tindakan manusia ketika mendapat tekanan atau pembatasan.

8. Hasrat Memberitahuan ialah keinginan menyampaikan ungkapan dari rasa kepada sesorang lain dengan cara penyampaian suara maupun insyarat.

9. Hasrat Simpati ialah keinginan dalam menyanggupi dengan langsung bertindak atas apa yang dirasakan oleh sesorang lain.

\section{Bencana}

Menurut UU No 24 Tahun 2007. Bencana ialah suatu kejadian yang menganggu kehidupan dan penghidupan masyarakat. Bencana memiliki sebab yakni ada faktor alam dan faktor non alam yang memiliki akibat yyang begitu besar terhadap kehidupan manusia yakni adanya korban jiwa, kerusakan lingkungan, kerugia meterial, dan dampak psikologis sesorang. Suatu kejadian bencana yang sering terjadi pada suatu wilayah yang mana tempatnya tergenang akan air yang mulanya tempat keringan mennjadi tergnenag akibat kapasitas air yang sangat banyak yakni pada tempat pertanian, pemukiman, pusat kota yang akibatnya memakan kerugian bagi hidup manusia dan perekonomian. ( Deasy, A. 2017).

\section{Dampak Banjir}

(Deasy, A. 2017). Bencana Banjir memiliki suatu akibat terhadap kehidupan masyarakat yakni berbagai sebab yang akan terjadi. Dampak Banjir terhadap kondisi masyarakaat. Kondisi sosial penduduk ialah suatu keadaan yang meilustrasikan kehidupan manusia terhadap nilai sosial. Kondisi sosial ada 4 diantaranya yakni Demografis, Kesehatan, Pendidikan dan kondisi Rumah. (Imas Karunia, 2012). 
a. Kondisi Demografis Ialah dari bahasa yunani ada kata demos artinya Rakyat dan kata grafein berati tulisan. Jadi sebagai studi ilmiah permasalhan penduduk berkenaan dengan jumlam, struktur, dan pertumbuah terkait bahaya banjir.

b. Kesehatan ialah suatu keadaan tubuh dalam keadaan prima entah tubuh, raga dan sosial yang menjadikan hidup produktif dalam kehidupan. Pelayanan Publik yakni masyarakat memiliki suatu upaya dalam menjaga kesehatan yakni promosi kesehatan, lingkungan, ibu serta anak, perbaikan gizi, pembasmi penyakit menulai untuk tujuannya ialah memelihara serta meningkatkan kesehataan dalam mencegah penyakit dengan tidak mengabaikan dari penyakit serta pemulihan kesehatan

c. Menurut UU No 20 Tahun 2003 mengenai Sistem Pendidikan Nasional. Pendidikan ialah upaya secara sadar dan terencana dalam mewujudkan suasana belajar serta proses pembelajaran agar peserta didik secara aktif dalam berkembang potensi diriinya dalam memilik kekuatas spiritual keagamaan, pengendalian diri, keperibadian, kecerdasan, akhlak mulia, serta keterampilan yang diperlukan dirinya, masyarakat, bangsa dan negara.

d. Kondisi Rumah. Rumah ialah keperluan maupu kebutuhan pokok manusia selain makanan dan pakaian ( sandang dan pangan ). Rumah baik ialah tempat terjaminnya kesehatan dan keamanan dengan kebersamaan keluarga yang engkap berdiri sendiri dan memiliki keawetan terhadap rekontruksi dari rumah tersebut yang memiliki unsur fisik yakni keadaan atap, dinding, lantai dan sebagainya

( Deasy, A. 2017). Dampak Banjir terhadao perekonomian masyarakat ialah suatu keadaan yang mengilustrasikan secara nyata terhadap kehiduapan manusia yang mempunyai niali ekonimi. Ekonomi sendiri sangat bersangkutann pada mata pencaria, pendapatan dan kepermilikan barang berharga. (Imas Karunia, 2012). Yakni sebagai berikut;

a. Mata Pencarian ialah kegiatan dalam menjalankan perkejaa untuk memperolah penghasilan yang diinginkan selama paaling rendah satu jam dalam satu minggu serta di lakukan secara berturut-turut dan tidak ada terputus yakni perkerjaan keluarga tanpa gaji yang membantu dalam usaha dari perekomomian.

b. Pendapatan ialah suatu penghasilan sktor formal dan non formal serta subsisten yang terhitung pada jangka waktu yag telah di tentukan yang di terima oleh anggota masyarakat maupn pemerintah berupa uang dan barang. 
c. Kepemilikan Barang ialah suatu barnag yang berharga dan ternilai oleh masyarakat sebagai suatu barang berharga yakni mobil, sepeda motor televisi atau radio srya Hp dan sebagainya dengan anggapan itu barang berharga yakni kepemilikan hewan ternak dan penguasaan lahan sawah dan sebagainya. Suatu bencana terjadi karena terpengaruhi budaya mata pencarian dan penalaran terhada skala lokal dalam sosial ekonomi dan kerugian ekonomi sebab nya ialah banjir karena memilik akibat akan kerusakan yang merugiakan seperti hancur perumahan dan tempat usaha.

Terbentuknya masarakat sebab adanya suatu hubunga antar anggota. Oleh sebab itu maka masyarakat ialah suatu sistem terbentuk dari kehdiupan manusia pada umumnya dikatakan ialah sistem kemasyarakayan. Menurut Emile Durkhem mengatakan masyarakat ialahh suatu kenyataan objektif secara mendiri memilik bebasa dari sesorang yang merupakan anggotanya. Sedangkan menurut Auguste Conte mengatakan masyarakat akan berkembang dengan penyesuaian dengan keadaan di dalamnya terhadap pola pengembangan diri. Dari pengembangan keadaan masyarakat maka akan terpengaruhinya keadaan setiap individu.

Dua Sudut pandang dari masyarakay yakni secara struktural ialah masyarakat ialah suatu unsur-unsur sosial atas kaidah, lembag, lapisan sosial masyarakar sekitar. Dan secara dinamika berkaitan adanya suatu proses dan perubahan sosial. Proses sosial ialah adanya intraksi timbal balik dari kehidupan manusia atau cara berhubungan antara individu ketika berintraksi yang membentuk sistem serya perubahan hidup yang telah ada. ( Putro, H. P. N., \& Jumriani, J. 2020).

Suatu kerusakan lingkungan oleh perilaku masyarakat akan menyebakan kerusakan lingkungan yang seharusnya diminimalisir dengan ketetuan pengendalian dari keserakanan manusia dalam mengeksplotasi sumber alam. Manusia tidak lahi menjadi makhluk alami yang selalu mengantungkan hidup pada alam namun sebaliknya manusia menjadi faktor penentu keberlangsungan alam. Cara pandangan seperti ini akan menunjuk suatu acaman tersembunyi saat manusia memiliki kekuasaan tertinggi dalam pegelolaan alam yakni proses eksplotasi. Tanpa di sadari yang berakibat bencana alam sebagai akibat ulah manusia itu sendiri. ( Mutiani, M. 2015).

Suatu kehidupan masyarakat memiliki nilai pemahaman sebagai suatu dalam memberi respon atas perilaku, tingkah laku, dan segaala sesuatu bekenaan dengan kegiatan masyarakat baik secara kelompok maupun secara mandiri. Suatu penilaian akan positif akan berakibat 
baik, Namun sebaliknya jika bersifat negatif maka akan hasinya berakibat burut pada objek suatu penilaian. Ada penilanan benntuk metafsis ialah harga suatu hal yang harus dicari dengan suatu perjalanan manusia dalam merespon sikap manusia yang lain. Suatu nilai pada dasarnya sudah terkandung dalam sesuatu maka dengan adanya pendidikan akan membantu sesoraang untuk menyadari dan mencari nilai yang mendalam serta memahami keterkiatan satu sama lain serta peranan dan kegunaan bagi kehidupan.( Subiyakto, B., \& Mutiani, M. (2019).

\section{Kesimpulan}

Perilaku merupakan adanya suatu respon terhadap tindakan dari setiap kegiatan manusia yang dapat diamati maupun tidak dengan adanya suatu intraksi/ saling berhubungan satu dengan yang lain yang ada di lingkungan sekitar. Lingkungan ialah semua faktor dari luar yang saling memperngaruhi suatu organisme hidup (biotic) ialah mahkluk hidup dan tidak hidup (abiotic) yakbi bahan kimia dan energi dan sebagainya. Masyarakat ialah kumpulan dari sesorang dalam membentuk sesuatu dan adanya suatu saling berinntraksi satu dengan yang lain dalam tujuan kebersamaan untuk menjalani suatu kehidupan di lingkungan sekitar dan juga mengatasi permasalahan atau isu-isu yang terjadi di tengah mereka.

Bencana ialah kejadian atau urutan suatu kerjadian yang mengancam dan menganggu bagi kehidupan suatu masyarakat. Sebabnya ialah faktor alam maupun faktor non alam serta faktor manusia sehingga berakibat timbul korban jiwa manusia, kerusakan lingkungan, kerugian harta benda serta berdampak pada psikologi. Bencana alam ialah suatu bencana yang mana berakiaat pada kejadian yang disebsbkan oleh gempa bumi, tsunami, Gunung meletus, banjir, kekeringan, angin topan dan tanah longsor. Bencana Non alam ialah bencana dari kejadian suatu peristiwa akibat oleh gagalnya teknologi, gagal modernisasi, epidemi, serta wabah penyakit. Bencana Sosial ialah bencana dari suatu peristiwa yang disebabkan oleh manusia yang meliputi konflik sosial antar kelompok atau antar komunitas masyarakat serta teror.

Banjir ialah suatu peristiwa disuatu tempat adanya genangan air yang melebihi kapasitas dari pembuangan aiir di wilayah tersebut yang menimbulkan suatu kerugian fisik, sosial serta ekonomi. Banjir juga acamanan pada setiap musim yang terjadi ketia meluapnya air dari saluran yanng mengenai wilayah tersebut yang sangat merugikan kehidupan makhluk hidup. Banjir ialah suatu kejadian peristiwa dimana dataran kering menjadi terkena tergenang air hingga tempat tersebut memiliki kapalitas air yaanng cukup tidak baik di suatu tempat tersebut yang di sebabkan oleh adanya curah hujan yang sangat tinggi dan topografi wilyahnya 
rendah sehingga tanahhnya tidak mampu menyerap air sedang berigitu banyaknya dalam waktu yang singkat dan menjadi lama untuk bisa terserap.

Manusia memiliki perilaku yang sangat baik dan tidak dalam mengingkan sesuatu yang diinginkan dalam memenuhi keperluan di kehidupan. Faktor-faktor yang mendorong manusia untuk hidup yakni Hasrat Sosial, Hasrat Mempertahankan diri Hasrat Berjuang, Hasrat Harga Diri, Hasrat Meniru, Hasrat Bergaul Hasrat Ingin Kebebasan, Hasrat Memberitahuan Hasrat Simpati.

Kondisi sosial ada 4 diantaranya yakni Demografis, Kesehatan, Pendidikan dan kondisi Rumah. Sebagai berikut Kondisi Demografis Ialah dari bahasa yunani ada kata demos artinya Rakyat dan kata grafein berati tulisan. Jadi sebagai studi ilmiah permasalhan penduduk berkenaan dengan jumlam, struktur, dan pertumbuah terkait bahaya banjir. Kesehatan ialah suatu keadaan tubuh dalam keadaan prima entah tubuh, raga dan sosial yang menjadikan hidup produktif dalam kehidupan. Pelayanan Publik yakni masyarakat memiliki suatu upaya dalam menjaga kesehatan yakni promosi kesehatan, lingkungan, ibu serta anak, perbaikan gizi, pembasmi penyakit menulai untuk tujuannya ialah memelihara serta meningkatkan kesehataan dalam mencegah penyakit dengan tidak mengabaikan dari penyakit serta pemulihan kesehatan Menurut UU No 20 Tahun 2003 mengenai Sistem Pendidikan Nasional. Pendidikan ialah upaya secara sadar dan terencana dalam mewujudkan suasana belajar serta proses pembelajaran agar peserta didik secara aktif dalam berkembang potensi diriinya dalam memilik kekuatas spiritual keagamaan, pengendalian diri, keperibadian, kecerdasan, akhlak mulia, serta keterampilan yang diperlukan dirinya, masyarakat, bangsa dan negara. Kondisi Rumah. Rumah ialah keperluan maupu kebutuhan pokok manusia selain makanan dan pakaian ( sandang dan pangan ). Rumah baik ialah tempat terjaminnya kesehatan dan keamanan dengan kebersamaan keluarga yang engkap berdiri sendiri dan memiliki keawetan terhadap rekontruksi dari rumah tersebut yang memiliki unsur fisik yakni keadaan atap, dinding, lantai dan sebagainya

\section{Saran}

Setiap Mahluk yang diciptakan oleh Allah Swt sangat bermanfaat satu dengan yang lainnya. Mahluk yang semperna ialah manusia yang diberikan akal yang berguna untuk membedakan benar dan salah yang diawali dengan bimbingan dan ajaran dari lingkup keluarga yakni peranan orang tua setalah itu adanya dunia pendidikan yang bertujuan menjadikan individu yang berguna bagi lingkungan sekitarnya serta bisa menyelesaikan masalah dalam kehidupan akan setiap berjalannya waktu. Dengan 2 lingkup keluarga dan pendidikan bisa 
menjadikan stiap individu memiliki perilaku diri yang baik yang menjalankan kewajiban untuk menjaga dan menyelesaikan suatu permasahan di lingkungan, bukan menjadikan individu tersebut menjadi perilaku diri yang tidak baik menjadikan lingkungan menjadi rusak dan akaibat nya pun di rasakan oleh semua kalangan sebab adanya keinginanan yang seharus bisa di kendalikan serta dapat di jaga dalam keberlanngsungnya kehidupan.

\section{References}

Akbar, R., Abedi, N., Handayani, R., \& Eka, U. M. (2017). Analisis Hasil Implementasi Business Intelligence Menentukan Daerah Rawan Banjir dan Kebakaran di Indonesia. JEPIN (Jurnal Edukasi dan Penelitian Informatika), 3(1), 65-70.

Akhmaddhian, S., \& Fathanudien, A. (2015). Partisipasi masyarakat dalam mewujudkan Kuningan sebagai kabupaten konservasi (studi di Kabupaten Kuningan). UNIFIKASI: Jurnal Ilmu Hukum, 2(1).

Deasy, A. (2017). Dampak Bencana Banjir Terhadap Kondisi Sosial Ekonomi masyarakat di Kecamatan Batu Benawa Kabupaten Hulu Sungai Tengah, Kalimantan Selatan. JPG (Jurnal Pendidikan Geografi), 4(4), 42-52.

Hotimah, O. PERILAKU MASYARAKAT TERHADAP FENOMENA BANJIR.

KRISTY, R. Aritikel Analisi kawasan rawan banjir Menggunakan SIG Kota Tarakan Kalimantan Utara Tahun 2020.

Mutiani, M. (2015). Pemanfaatan Puisi Sebagai Sumber Belajar Ips Untuk Menumbuhkan Kesadaran Lingkungan Peserta Didik Di SMP Negeri 6 Banjarmasin. Jurnal Pendidikan Ilmu Sosial, 24(2), 199-208.

Putro, H. P. N., \& Jumriani, J. (2020). KEHIDUPAN SOSIAL DAN EKONOMI MASYARAKAT BANTARAN SUNGAI A SEBAGAI SUMBER BELAJAR IPS.

Subiyakto, B., \& Mutiani, M. (2019). Internalisasi nilai pendidikan melalui aktivitas masyarakat sebagai sumber belajar ilmu pengetahuan sosial. Khazanah: Jurnal Studi Islam Dan Humaniora, 17(1), 137-166.

Subiyakto, B., Mutiani, M., \& Hidayat Putra, M. A. (2019).

Virgatama, D. (2021). GAMBARAN PENGETAHUAN DAN SIKAP TENTANG KESEHATAN GIGI PADA IBU HAMIL DI KABUPATEN BANGLI TAHUN 2021 (Doctoral dissertation, Poltekkes Kemenkes Denpasar).

WARMANSYAH ABBAS, E. R. S. I. S. (2018). Kehidupan Sungai Masyarakat Kuin Kota Banjarmasin. 